\title{
Satellite-Based Monitoring of Ecosystem Functioning in Protected Areas: Recent Trends in the Oak Forests (Quercus pyrenaica Willd.) of Sierra Nevada (Spain)
}

\author{
M.A. Dionisio, D. Alcaraz-Segura and J. Cabello \\ Andalusian Center for the Assessment and Monitoring Global Change (CAESCG) \\ Dept. Plant Biology and Ecology, University of Almería
}

Spain

\section{Introduction}

The implementation of monitoring and early warning programs on the ecological status of natural areas is increasingly recognized as an environmental priority (Lovett et al., 2007). However, the development of such programs faces important challenges derived from the many requirements that ecological indicators should fulfill to achieve effective monitoring and alert systems (Oyonarte et al., 2010). Nowadays, ecosystem functioning characterization has become crucial for the monitoring and management of ecosystems due to several reasons (Cabello et al., 2008). First, the evaluation of functional features of ecosystems, such as the carbon gains dynamics, complements the traditional description of ecosystems based solely on vegetation structural features (like physiognomy, dominant species, or floristic composition) derived from few plot observations (Mueller-Dombois \& Ellenberg, 1974; Stephenson, 1990; Alcaraz-Segura et al., 2009a). Second, ecosystem functional attributes show a much quicker response to environmental changes than structural ones (Milchunas \& Lauenroth, 1995; Wiegand et al., 2004; Alcaraz-Segura et al., 2008a). Third, functional traits are related to key ecological processes that provide a direct measurement of key ecosystem services (Oyonarte et al., 2010; Paruelo et al., 2011; Volante et al., In press). Finally, remote sensing tools can be used to monitor ecosystem functional attributes over extensive areas, in different regions, and with a fast-revisiting frequency (Paruelo et al., 2005; Pettorelli et al., 2005; Baldi et al., 2008; Cabello et al., 2008; Alcaraz-Segura et al., 2009a). The use of satellitederived information allows for tracking the integrity of key ecological processes and their spatial and temporal variability with the advantage of using common protocols throughout the Earth (Dale \& Beyeler, 2001). In this sense, several works have shown the ability of timeseries of satellite images to assess the existence of long-term ecosystem functional changes both at the regional (Baldi et al., 2008; Alcaraz-Segura et al., 2010b) and local (AlcarazSegura et al., 2008a; Alcaraz-Segura et al., 2008b; Alcaraz-Segura et al., 2009b; Cabello et al., Accepted) scales. 
Remote sensing tools can be used to detect both evident functional changes produced by land-use transformations (Volante et al., In press), and other subtle and less noticeable changes including insect outbreaks (Kharuk et al., 2003), wind (Yuan et al., 2002), droughts (Tucker \& Choudhury, 1987) or floods (Sanyal \& Lu, 2004), fires (Riano et al., 2002), pollution (Chu et al., 2003), etc. These impacts may derive in significant changes in key ecological processes, for instance, carbon balance, microclimate, and biodiversity patterns (Turner, 2005; Lovett et al., 2006; Perry \& Millington, 2008). Remote sensing has been proved to be useful for monitoring this kind of "within-state" changes (Vogelmann et al., 2009). In particular, satellite-derived spectral vegetation indices, such as the Enhanced Vegetation Index (EVI) and the Normalized Difference Vegetation Index (NDVI), are considered the most useful approach to monitor ecosystem responses to environmental changes (Pettorelli et al., 2005). Vegetation indices constitute the most feasible approach to estimate primary production at the regional scale (Paruelo et al., 1997) since they show a linear response to the intercepted fraction of photosynthetically active radiation (FPAR) (Hanan et al., 1995), which represents the conceptual basis to relate vegetation indices with net primary production (NPP) through Monteith's model (Monteith, 1972) (equation 1).

$$
\mathrm{NPP}=\mathrm{PAR} * \mathrm{FPAR} * \mathrm{RUE}
$$

Where NPP is the Net Primary Production, PAR is the amount of incident Photosynthetically Active Radiation, FPAR is the fraction of that PAR that is intercepted by vegetation green tissues, and RUE is the Radiation Use Efficiency that plants have to transform that radiation into organic carbon compounds. Given this direct relationship with NPP, the most integrative descriptor of ecosystem functioning (McNaughton et al., 1989; Virginia \& Wall, 2001), vegetation indices are frequently used to derive indicators of ecosystem functioning such as the annual amount of carbon absorbed by vegetation, or the seasonality and phenology of the carbon gain dynamics (Pettorelli et al., 2005; AlcarazSegura et al., 2006).

To evaluate the usefulness of satellite-derived vegetation indices for monitoring functional changes within protected areas, we focused on the Sub-Mediterranean Pyrenean oak forests (Quercus pyrenaica Willd.) of the Sierra Nevada National Park (Spain). These forests are considered as a Natural Habitat of Community Interest (Quercus pyrenaica oak woods and Quercus robur and Quercus pyrenaica oak woods from Iberian northwestern, Directive 92/43/CEE) (García \& Mejías, 2009). The Pyrenean oak forests are a quasi-endemic habitat of the Iberian Peninsula. The only non-Iberian representations are in the Central West of France and in the Rif Mountains of northern Morocco. In the South of Spain, the Pyrenean oak is considered as a vulnerable species (Blanca \& Mendoza, 2000). Sierra Nevada oak populations are considered of great biogeographical importance since they constitute the southernmost Iberian representation of these forests (Molero et al., 1992) and they are considered relict deciduous forests in the Southern Mediterranean region (Blanca \& Mendoza, 2000; Blanca, 2001). Several stands of these forests in the Sierra Nevada National Park have an unfavorable conservation status (Molero et al., 1992; Bonet et al., 2010). Multiple global change drivers have an impact on these southernmost woodlands of Quercus pyrenaica in the Iberian Peninsula. Historically, these populations have been subjected to intense human disturbances (logging, fires, grazing, agriculture, etc). As a result, these forests are highly fragmented and display low ecological maturity (García \& Mejías, 2009) that threatens their long-term conservation. Currently, trends towards temperature rises and precipitation decreases have been hypothesized as the main constraining factor reducing 
peripheral populations in Sierra Nevada National Park (Molero et al., 1992; Bonet et al., 2010). Quercus pyrenaica is a winter semi-deciduous tree with high water demand during the summer. Hence, the predicted lengthening of the summer dry period associated to a reduction in the annual precipitation and the increase in the mean annual temperatures (Bonet et al., 2010) could impose a serious challenge for the regeneration of these forests (Molero et al., 1992; Blanca \& Mendoza, 2000). Unfortunately, compared to the wide availability of studies of forest ecology in Europe, there is an enormous lack of knowledge of the conservation status and ecology of Pyrenean oak woodlands in the Iberian Peninsula (García \& Mejías, 2009).

Our objective in this study was to use a satellite-based approach to monitor changes in ecosystem functional attributes of the oak forests of the Sierra Nevada National Park (Figure 1). This approach is based on the characterization of the seasonal dynamics and the interannual variability and trends of the Enhanced Vegetation Index (EVI). From the mean annual curve of EVI of each forest patch, we derived functional attributes related to primary production, seasonality, and phenology of the forests. Finally, by contrasting the baseline conditions of each forest patch with the long-term observed trends for the period 2001-2009, we identified processes of functional changes happening in these forests that could guide management actions. We propose this satellite approach as a near-real-time tool to provide managers with ecologically meaningful assessments of the ecosystem status based on lowcost but effective information.

\section{Methodology}

\subsection{The Pyrenean oak forests of Sierra Nevada National Park}

Sierra Nevada National Park is located in the southeast of the Iberian Peninsula (Figure 1). This National Park protects the best samples of high and medium Mediterranean mountainous ecosystems (MMARM, 2004). This park is a hot spot for plant species richness (Blanca et al., 1998; Blanca, 2001) and invertebrate biodiversity. Its altitude (several summits over 3000 m.a.s.l.), its proximity to Africa, and steep altitudinal gradient constitute the main ecological and evolutionary factors determining its high biodiversity.

The Pyrenean oak forests (Figure 1) of Sierra Nevada represent a conservation priority for the Park managers. There are nine locations distributed on siliceous soils both in the northwestern and southern slopes of the mountain range. In general, they are associated to major river valleys and within an altitudinal range of 1200 to 1900 m.a.s.l. (Table 1).

\subsection{Monitoring forest ecological status with EVI}

Our monitoring approach was based on the characterization of ecosystem functional attributes derived from the seasonal dynamics of the Enhanced Vegetation Index (EVI). The EVI calculates the normalized difference in reflectance between the red light that is absorbed in photosynthesis and the strong reflection of near infra-red light caused by the cell structure of the leaves. It also includes a third wavelength (blue) that is used to correct the influence of the atmosphere and the soil. EVI is defined according to equation 2 (Huete et al., 1997).

$$
E V I=G \frac{N I R-R}{N I R+C_{1} R-C_{2} B+L}
$$


Where NIR, $\mathrm{R}$ and $\mathrm{B}$ represent the reflectance in the near infrared, red, and blue wavelengths, $C_{1}(6)$ and $C_{2}$ (7.5) are coefficients of atmospheric resistance, $G(2.5)$ is the gain factor, and $\mathrm{L}(1)$ is a soil correction factor.

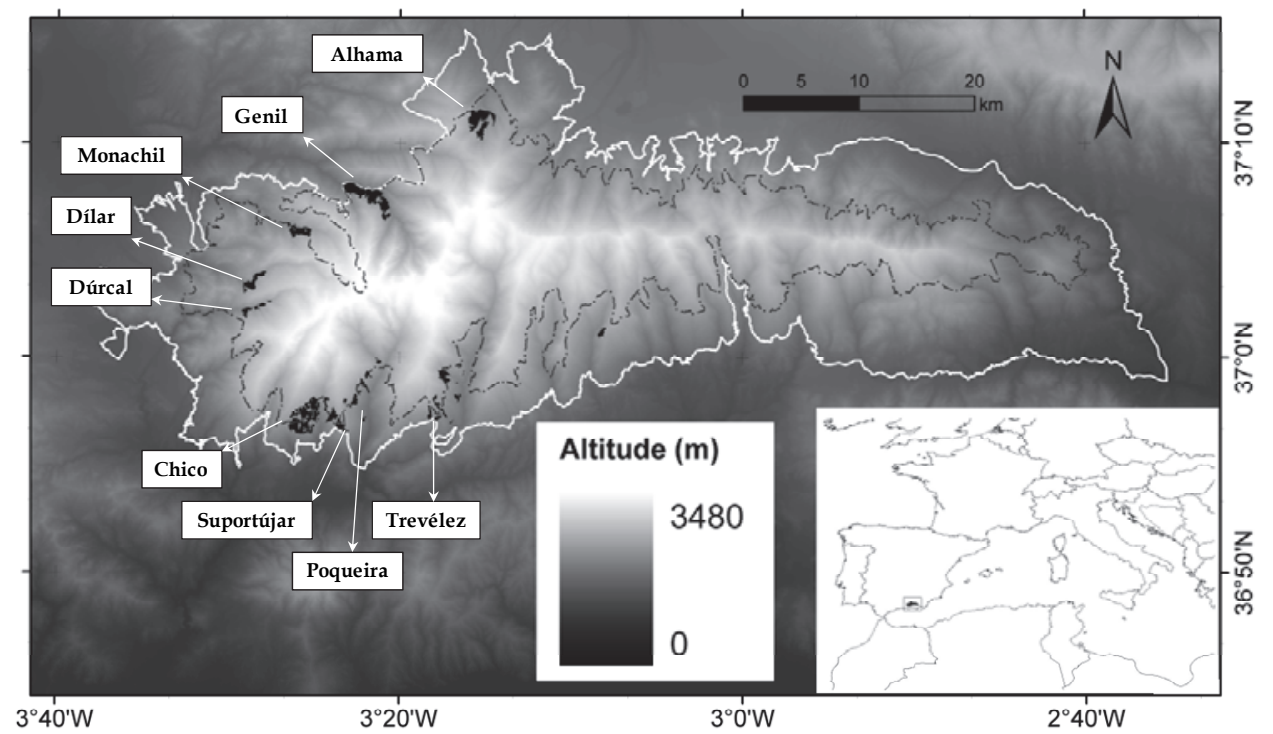

Fig. 1. Distribution of the Pyrenean oak forest patches (Quercus pyrenaica) in the Sierra Nevada National Park (southeastern Spain). Forest patches are named according the river basin where they are located: Alhama, Genil, Monachil, Dílar, and Dúrcal, in the northern slope; and Chico, Soportújar, Poqueira, and Trevélez in the southern slope.

Our approach uses satellite images of the Enhanced Vegetation Index captured by the Moderate Resolution Imaging Spectroradiometer (MODIS) sensor onboard the Terra satellite from 2001 to 2009 (Product MOD13Q1). These images have a temporal resolution of 16 days (23 images per year) and a spatial resolution of $231 \times 231 \mathrm{~m}$. We used the Quality Assessment information to filter out low quality data, submitting images to a purification process which removes those pixels affected by high aerosol content, clouds, snow, shadows, and water. From this dataset, we first calculated the 9-year mean EVI seasonal curve for each oak forest site (Figure 1). For this, we only used pixels with more than $75 \%$ of their surface occupied by oak woods. Then, the following descriptive attributes of the ecosystem functioning were derived (Figure 2): The EVI annual mean (EVI_mean), an estimator of primary production; the EVI seasonal (or intra-annual) coefficient of variation (EVI_sCV), an indicator of seasonality of carbon gains; the EVI maximum (MAX) and minimum (MIN) values, indicators of the maximum and minimum photosynthetic capacities respectively; and the dates when the maximum (DMAX) and minimum (DMIN) EVI values are reached, two descriptors of the phenology of vegetation greenness. These attributes are widely used and have clear biological meanings (Pettorelli et al., 2005; Alcaraz-Segura et al., 2009a). 
To explore the existence of inter-annual trends of ecosystem functioning during the 20012009 period in the oak forests of Sierra Nevada, we followed the methodology suggested by Alcaraz-Segura et al. (2009b). In addition to the evaluation of long-term trends of the EVI_mean, we also evaluated the existence of significant trends within each of the 23 images (16-day periods) of the year by means of the Mann-Kendall trend test, a non-parametric trend test robust against non-normality, heterocedasticity, outliers, and serial dependence. For each pixel, we obtained the slope of the trends through the Sen's Method (Hirsch et al., 1982). Significant trends were considered with p-values $<0.05$.

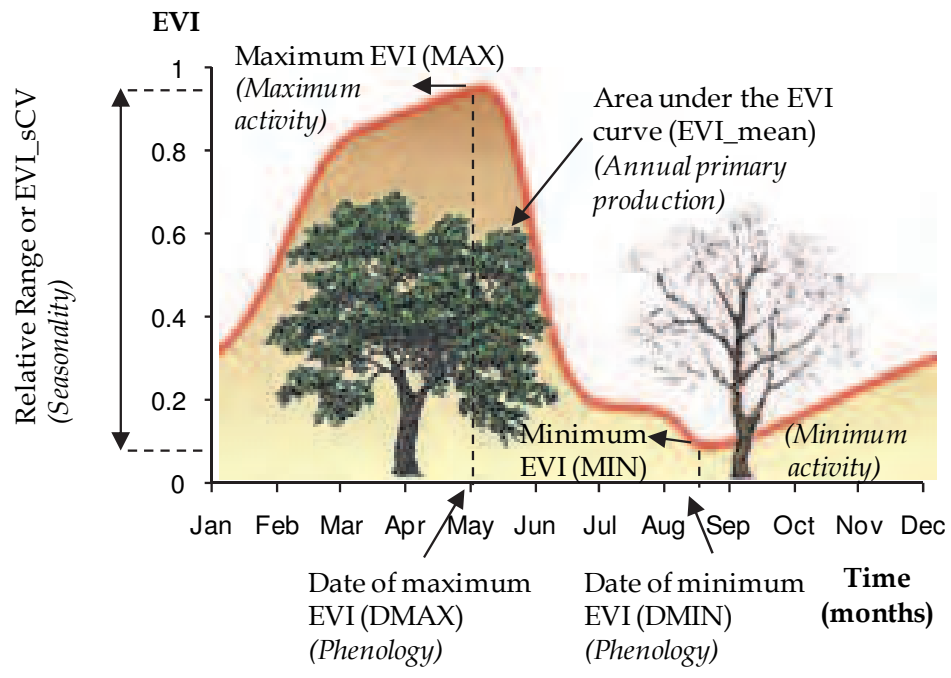

Fig. 2. Functional attributes of the EVI seasonal curve related to ecosystem primary production, seasonality, and phenology. EVI_mean: EVI annual mean, EVI_sCV: EVI seasonal Coefficient of Variation (SD/EVI_mean), MAX: Maximum EVI annual value, MIN: Minimum EVI annual value, DMAX: Date in which is reached the maximum EVI value, DMIN: Date in which is reached the minimum EVI value. These attributes have a clear biological meaning, the EVI_mean is an indicator of the fraction of the radiation used by plants and net primary productivity, MAX and MIN are indicators of the maximum and minimum photosynthetic activity, EVI_sCV is one indicator of seasonality of carbon gains, and DMAX and DMIN are indicators of phenology. Image modified from (Cabello et al., 2010) and G. Baldi from http://lechusa.unsl.edu.ar.

\subsection{Statistical analyses}

To evaluate whether there exist differences in the EVI attributes among the nine oak woods studied in Sierra Nevada, we performed analysis of variance (ANOVA) only when either raw or transformed attributes fulfilled the necessary parametric requirements of normality and homoscedasticity. To reach normality, for EVI_mean we applied a natural Logarithm (Ln) transformation (Shapiro-Wilk, $\mathrm{W}=0.990, \mathrm{p}=0.266, \mathrm{n}=177$; Levene's Test $\mathrm{F}=0.474$, 
$\mathrm{p}=0.873, \mathrm{n}=177$ ) and for EVI_sCV a Box-Cox transformation (Shapiro-Wilk, W=0.983, $\mathrm{p}=0.031, \mathrm{n}=177$; Levene's Test $\mathrm{F}=1.951, \mathrm{p}=0.055, \mathrm{n}=177)$. The slight but not significant deviation from normality for the EVI_sCV data did not affect results. For those attributes that even transformed did not fulfill normality (MAX, MIN, DMAX, and DMIN), the analysis was conducted using the non-parametric Kruskal-Wallis test. To determine which groups significantly differed from each other, we used multiple post hoc comparisons, using the Tukey test for EVI_mean and EVI_sCV, and the Bonferroni test for MAX, MIN, DMAX, and DMIN. See Figure 5.

\section{Results}

\subsection{Functional characterization of Sierra Nevada oak woods}

The Pyrenean oak forests of Sierra Nevada showed a heterogeneous spatial behavior in terms of their EVI seasonal dynamics. In general, woods of the southern slope of Sierra Nevada displayed greater annual vegetation greenness and longer growing seasons than those from the northern slope (Figures 3 and 4). The seasonal EVI curve of the oak woods in the northern slope (Figure 3) showed a gradual increase in productivity that begins around March and that reaches its maximum peak in late May - early June (Figure 5e). Then, senescence takes place at a similar but slightly lower rate than growth. In contrast, the EVI curves of southern-slope woods (Figure 4) show a later but much steeper start of the growing season in late April - early May, reaching the EVI maximum value in June, as in the northern slope woods (Figure 5e). Then, EVI maintains a slowly decreasing plateau until around November, when a less pronounced end of the growing season than in the northern woods occurs.

Statistical comparisons of the EVI attributes (Figure 5) among oak woods also revealed the former differences. In general, Northern oak woods had significantly lower EVI_mean values than southern ones (ANOVA: $F=33.56 ; \mathrm{p}=0.0000 ; \mathrm{n}=177$; Figures 5a and 6a). Dílar woods (Figure 3d) showed the lowest values and Poqueira (Figure 4c) the highest. The EVI_sCV displayed greater values in the north than in the south (ANOVA: F=29.35; $\mathrm{p}=0.0000 ; \mathrm{n}=177$; Figures $5 \mathrm{~b}$ and $6 \mathrm{~b}$ ) and a much greater dispersion of data in the north. Although MAX values (Figures $5 \mathrm{c}$ and $6 \mathrm{c}$ ) showed significant differences between some oak woods (Kruskal Wallis: $\mathrm{H}=36.94 ; \mathrm{p}=0.0000 ; \mathrm{n}=177$ ), there were no clear differences between the northern and southern woods. In general, Max values showed little inter-woods, but large intra-wood variation. We hypothesize that this larger intra-wood variation could be related to greater altitudinal range, such as in Alhama, Genil, Chico and Trevélez (Table 1). DMAX did not either significantly differ between the northern and southern woods, happening in May-June in all oak woods but coming about later with altitude. The increase of intra-wood variability with greater altitudinal variation was also observed in DMAX (Kruskal Wallis: H=64.61; $\mathrm{p}=0.0000 ; \mathrm{n}=177$; Figures 5e and 7a). Regarding MIN values, southern woods showed significantly higher values than northern woods (Kruskal-Wallis: $\mathrm{H}=126.05 ; \mathrm{p}=0.000 ; \mathrm{n}=177$; Figures $5 \mathrm{~d}$ and $6 \mathrm{~d})$, which is directly related to EVI_mean (Figures 5a and 6a) and EVI_sCV (Figures 5b and 6b). Contrary to DMAX, DMIN showed great variability both within and among woods (from November to April) (Figures $5 \mathrm{f}$ and 7b) (May-July), with earlier DMIN values in the northern woods than in the southern ones (Kruskal-Wallis: $\mathrm{H}=86.93 ; \mathrm{p}=0.0000 ; \mathrm{n}=177$; Figures $5 \mathrm{f}$ and $7 \mathrm{~b}$ ). 
요유 혼

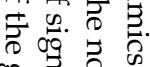

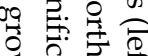

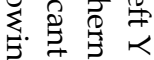

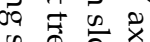

$\rightarrow \stackrel{\circ}{\circ}$ ซ 2

$\sum$ ए

Z ¿ ᄅ. こ

¿ ?

융 융

है के प्त

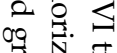

స્ટ

寻恋
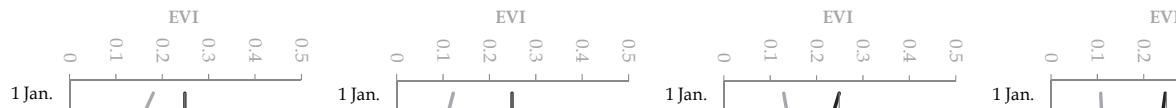

17 Jan.

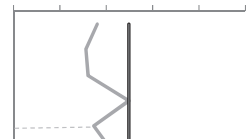

22 Mar.

23 Apr.

9 May.
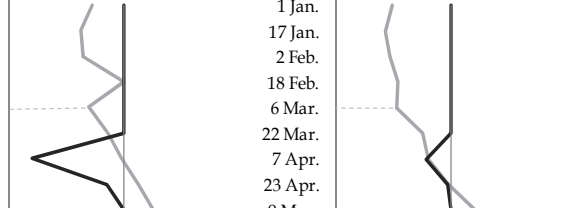

un.

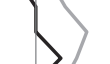

22 Mar.

7 Apr.

23 Apr.

9 May.

25 May.

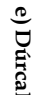

10 Jun

$17 \mathrm{Jan}$

$18 \mathrm{Feb}$.

6 Mar.

$22 \mathrm{Mar}$.

7 Apr.

$23 \mathrm{Apr}$.

9 May.

25 May.

$\underset{\Xi}{\ominus}$

10 Jun.

$12 \mathrm{Jul}$.

13 Aug.

29 Aug.

14 Sep.
30 Sep.

16 Oct.

$1 \mathrm{Nov}$.

$17 \mathrm{Nov}$

3 Dec.

3 Dec.

$19 \mathrm{Dec}$.

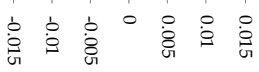

EVI Trends 19 Dec.

क $\mathrm{N}=$

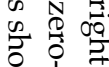

之京文

守芑炁.

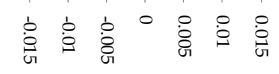

EVI Trends

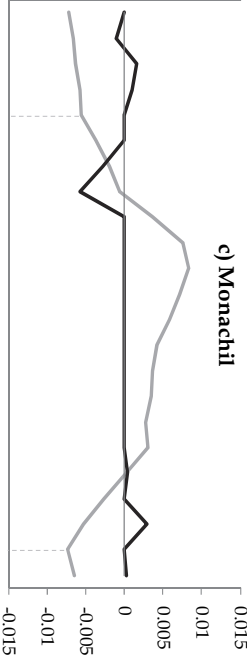

EVI Trends

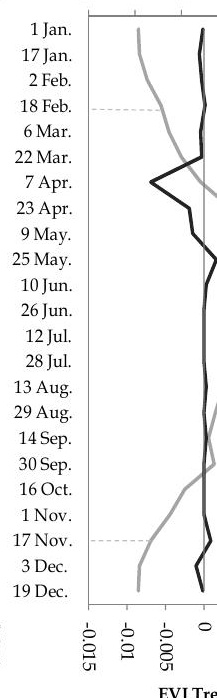

VI Tre 

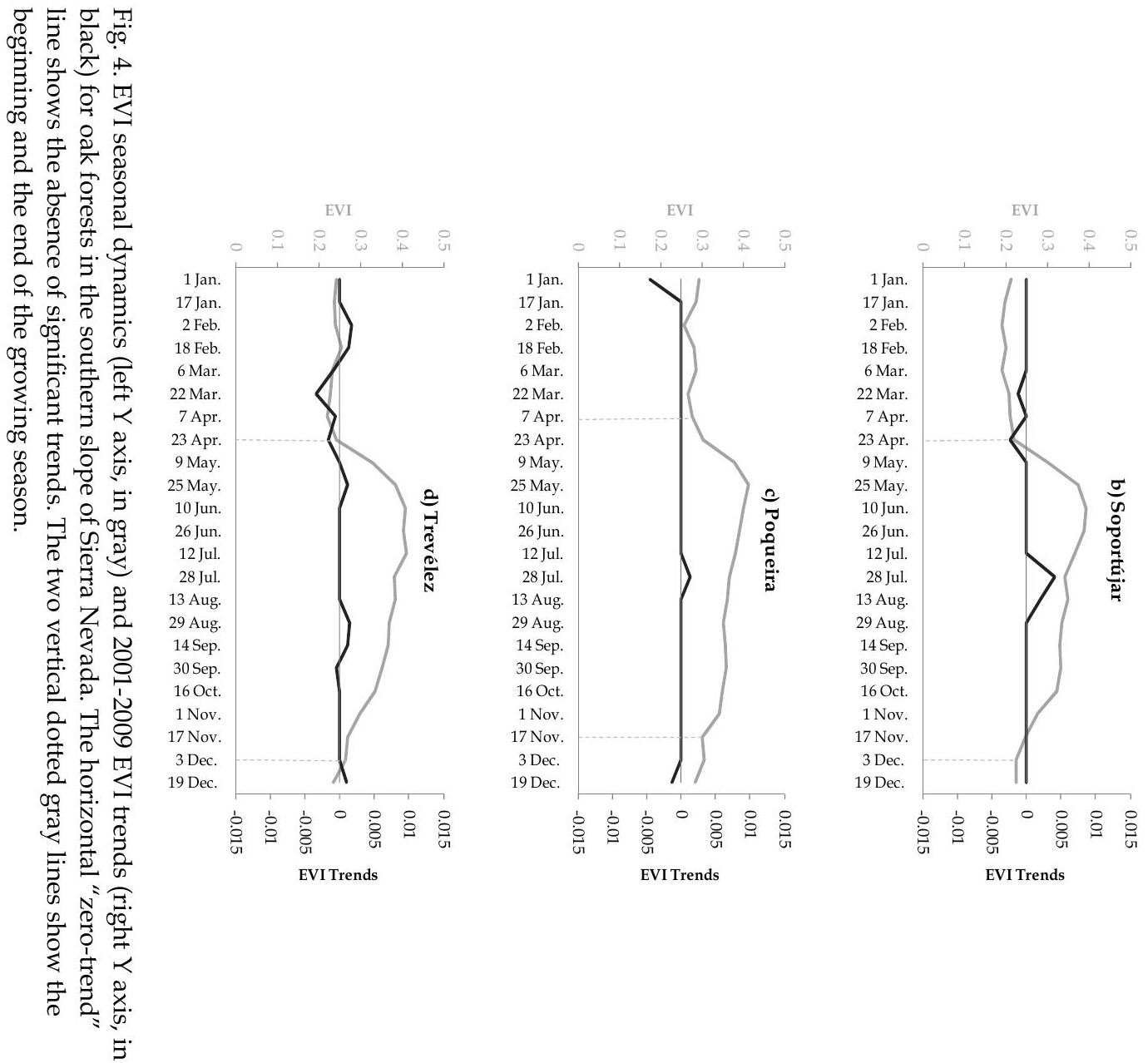


\subsection{Functional changes in Sierra Nevada oak woods}

We found significant functional changes happening in the Sierra Nevada oak woods during the 2001-2009 period. Though we did not observe significant long-term trends in the annual synthetic EVI attributes, particular periods of the year did show significant EVI trends. The greatest significant trends occurred at the beginning of the growing season, when strong EVI decreases were observed (March-April), particularly in the northwestern slope (Figure 3 ). A clearly marked downward trend in productivity was observed between 7 th April - 23rd April), which took place in four out of the five northwestern oak woods (Genil, Monachil, Dílar, and Dúrcal, Figures 3b, 3c, 3d, and 3e). Alhama oak wood (Figure 3a) was the only exception, displaying no long-term trends. Some northern woods also showed small positive EVI trends in November (Genil, Monachil, and Dílar; Figures 3b, 3c, and 3d) and in the early-summer (Genil, Dílar, and Durcal).

The southern oak woods (Figure 4) also showed a decrease of vegetation greenness at the beginning of the growing season (except Poqueira, Figure 4c), but less deep than in the northern woods. In addition, EVI increases were observed in middle to late summer in three out of four southern woods (Soportújar, Poqueira, and Trevélez (Figures 4b, 4c, and $4 d)$.

\section{Environmental traits}

\# of pixels with EVI_mean trends

\begin{tabular}{|c|c|c|c|c|c|c|c|}
\hline Oak woods & $\begin{array}{c}\text { Area (ha)/ } \\
\text { Pixels } \\
\text { sampled (n) }\end{array}$ & $\begin{array}{c}\text { Altitudinal } \\
\text { range }\end{array}$ & Aspect & Slope & $\begin{array}{l}\text { Positive } \\
\text { Sen's } \\
\text { slope (+) }\end{array}$ & $\begin{array}{l}\text { Negative } \\
\text { Sen's } \\
\text { slope (-) }\end{array}$ & $\begin{array}{c}\text { M-Kendall } \\
\text { Significant } \\
(\mathrm{p} \leq 0.15) \\
(+/-)\end{array}$ \\
\hline Alhama & $266 / 36$ & $1443-1838$ & $\mathrm{NE}$ & $25^{\circ}$ & 0 & 20 & $0 / 1$ \\
\hline Genil & $356 / 51$ & $1272-1792$ & $\mathrm{~N}$ & $30^{\circ}$ & 0 & 29 & $0 / 14$ \\
\hline Monachil & $104 / 15$ & $1630-1842$ & $\mathrm{~N}$ & $27^{\circ}$ & 0 & 8 & $0 / 1$ \\
\hline Dílar & $111 / 14$ & 1594-1884 & NW & $31^{\circ}$ & 1 & 7 & $0 / 1$ \\
\hline Dúrcal & $58 / 4$ & $1598-1833$ & W & $28^{\circ}$ & 0 & 2 & $0 / 0$ \\
\hline Chico & $445 / 39$ & $1459-1870$ & S & $17^{\circ}$ & 1 & 21 & $0 / 9$ \\
\hline Soportújar & $46 / 4$ & $1652-1755$ & SW & $17^{\circ}$ & 1 & 1 & $0 / 0$ \\
\hline Poqueira & $105 / 5$ & $1635-1888$ & SE & $25^{\circ}$ & 1 & 2 & $0 / 0$ \\
\hline Trevélez & $167 / 9$ & $1397-1880$ & $\mathrm{E}$ & $24^{\circ}$ & 1 & 5 & $0 / 1$ \\
\hline
\end{tabular}

Table 1. Environmental traits and EVI_mean trends during the 2001-2009 period in nine Quercus pyrenaica oak woods of Sierra Nevada National Park. Forest patches are named according the river basin where they are located: Alhama, Genil, Monachil, Dílar, and Dúrcal, in the northern slope; and Chico, Soportújar, Poqueira, and Trevélez in the southern slope. 

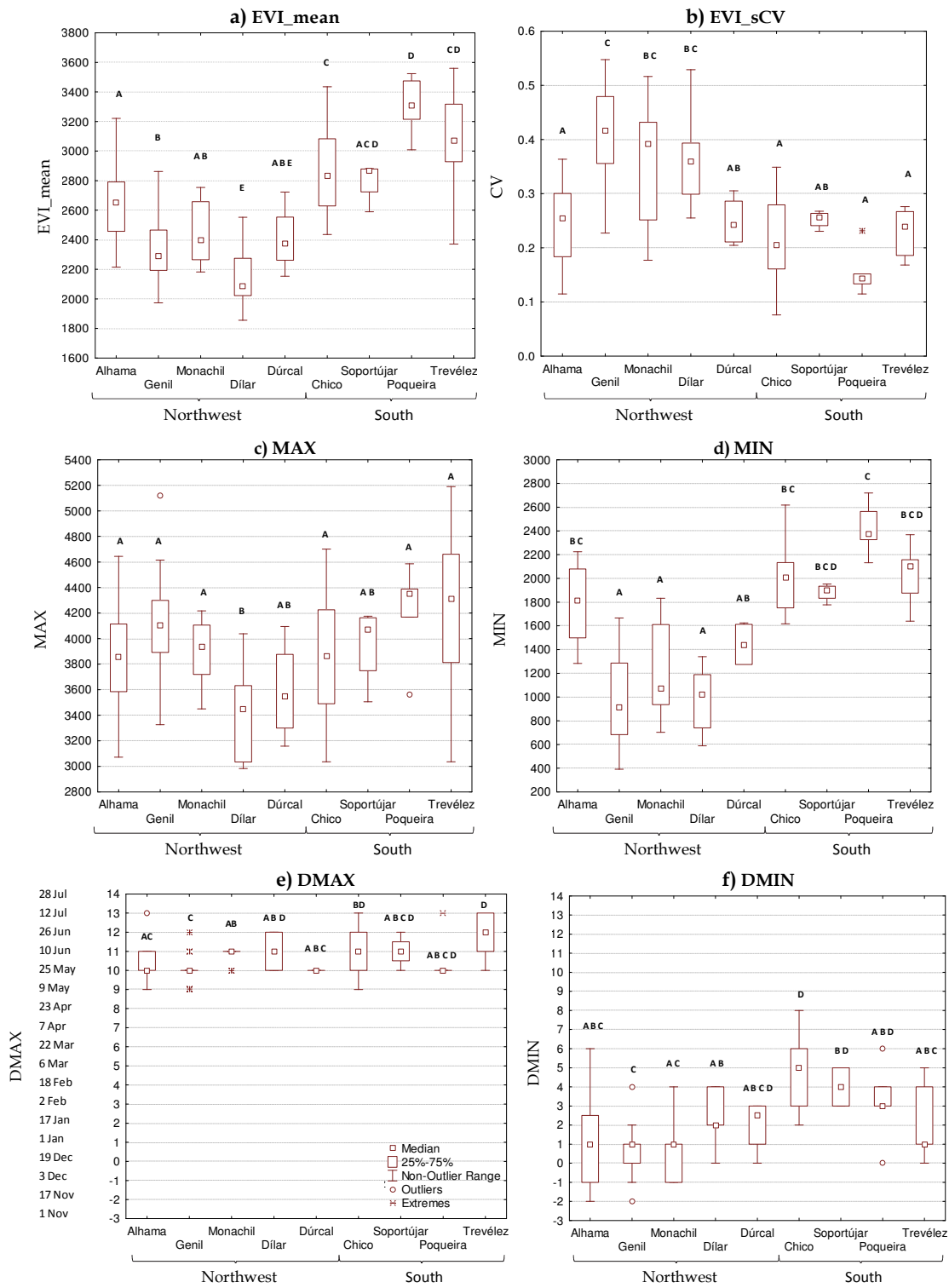

Fig. 5. Functional characterization of the oak woods of Sierra Nevada (Spain) based on the EVI attributes for the 2001-2009 period. Letters show significant differences in post hoc comparisons. a) EVI annual mean, an estimator of annual primary production; b) EVI seasonal Coefficient of Variation, a descriptor of seasonality; c) Maximum and d) Minimum EVI annual values, indicators of the maximum and minimum photosynthetic activity; Dates when the e) Maximum and f) Minimum EVI values are reached, indicators of phenology. 


\section{Discussion}

\subsection{Baseline conditions and trends in the ecosystem functioning of the Pyrenean oak woods of Sierra Nevada National Park}

Our approach, based on a time series of satellite-derived images of the EVI, provided a description of how different attributes of ecosystem functioning change across the remaining locations of Pyrenean oak woodlands in Sierra Nevada. This reference description provides the baseline conditions of ecosystem functioning that can be used to assess the effects of environmental changes on ecosystems processes. The Pyrenean oak woodlands of Sierra Nevada showed a unimodal EVI seasonal dynamics with a unique and well-defined growing season centered in summer and winter minima, as observed in previous works (Alcaraz-Segura et al., 2009a). Differences among locations mainly occurred during the winter non-growing season and at the beginning of the growing season (spring) and were mainly related to the location in the north or south slopes of Sierra Nevada. The lower EVI_mean values in the northern oak woods (Figure 5a) are closely linked to the presence of lower winter MIN values than in the southern woods (Figure 5d) and with the more abrupt EVI decrease during the autumn. In contrast, southern woods maintained relatively high EVI values throughout their longer growing season (Figure 4). The greater annual vegetation greenness of southern woods is probably due to the greater incidence of solar radiation that favors longer growing seasons, milder temperatures during the winter, and an extra water supply from humid air masses coming from the Mediterranean sea that compensate the very high evapotranspiration rates during the summer, in comparison to the colder and more continental locations of the northern slope (Costa Tenorio et al., 2005). Contrary, summer maximum EVI values (MAX) would not cause significant differences in annual vegetation greenness between the northern and southern locations. In consequence, the northern slope shows much greater seasonality (EVI_sCV) than the southern slope since MAX values are similar in both orientations, though the northern woods showed lower MIN values than the southern ones (Figure $5 \mathrm{~d}$ ). From the analysis of the shape of the EVI seasonal curves and according to previous studies (Alcaraz-Segura et al., 2009a), the main limiting factors for vegetation greenness in the oak woodlands of Sierra Nevada are low winter temperatures and lower solar irradiation in the northern slope, which favors a longer presence of snow (Figure $5 \mathrm{~d})$. An important point to consider is that the greater vegetation greenness of the southern woodlands during the non-growing season is not related to the activity of the oak trees (because they are winter semi-deciduous), but to the shrubs and herbaceous vegetation occupying the undergrowth vegetation and the patches without trees (Figure 8). In the same way, since the snow melt happens faster and earlier in the southern woods, undergrowth vegetation is also responsible for the earlier and more pronounced rise in vegetation greenness during the start of the growing season than in the northern woods (Figure 3).

Our study also showed that though the oak woodlands of Sierra Nevada have not experienced significant changes of the EVI_mean during the 2001-2009 period, they have suffered seasonal functional changes that mainly affected the beginning of the growing season. In contrast to this relative stability of annual mean vegetation greenness (EVI_mean) since 2001, previous evaluations showed a significant increase in vegetation greenness throughout the eighties and nineties in Sierra Nevada (see Alcaraz-Segura et al., 2008b for the 1981-2003 period, and Alcaraz-Segura et al., 2009b for the 1982-2006 period). Such evaluations used the GIMMS-AVHRR (Global Inventory Modelling and Mapping Studies Advanced Very High Resolution Radiometer) NDVI dataset. Though there is some debate on the existence of a long-term bias in the GIMMS dataset towards NDVI increases in some 
regions of the world including the Canadian Boreal forest (Alcaraz-Segura et al., 2010a) and South America (Baldi et al., 2008), the NDVI increases observed in Sierra Nevada with GIMMS during the 1980's and 1990's agreed with other independent datasets. AlcarazSegura et al. (2010b) showed that the positive NDVI trends that Sierra Nevada displayed in previous studies with the GIMMS dataset were observed for the 1981-1999 period using other independent datasets such as PAL (Pathfinder AVHRR Land), FASIR (FourierAdjustment, Solar zenith angle corrected, Interpolated Reconstructed), and LTDR (Land Long-Term Data Record) datasets. Positive NDVI trends were also observed in Sierra Nevada during the 1989-2002 period using the MEDOKADS (Mediterranean Extended Daily One-km AVHRR Data Set) archive (Martínez \& Gilabert, 2009).

The EVI decrease observed at the beginning of the growing season during the 2000-2009 period in Sierra Nevada oak woodlands (Figures 3 and 4), is also in contrast with the NDVI seasonal increase in autumn, winter, and spring that was reported for the 1982-2006 period using GIMMS images of the entire Park (see Figure 2 in: Alcaraz-Segura et al., 2008a). Such contrasting trends lead to think that the increase of spring vegetation greenness that occurred throughout de eighties and nineties (Alcaraz-Segura et al., 2008a) ended around the year 2000 when the spring started to return to lower greenness values. Yet, the trends towards greater vegetation greenness in autumn and winter reached during the eighties and nineties (AlcarazSegura et al., 2008a) was maintained after the year 2000, since we did not find significant EVI trends in these seasons. The strong EVI decreases at the beginning of the growing season and the presence of some EVI summer increases during the senescence period lead to think that the growing season of southern oak woods (Figure 4) might be starting later but strengthening towards the summer (with the exception of Poqueira; Figure 4c).

An important outcome of our work is that significant functional changes, i.e. a significant decrease of vegetation greenness at the beginning of the growing season, took place in Sierra Nevada oak woodlands without implying significant trends in the annual averages. Despite the EVI annual mean, an estimator of annual primary production, is extensively used as an integrative descriptor of ecosystem functioning and status, our work highlights the importance of studying variables beyond the annual summaries (like seasonality and phenology) as significant trends in particular months of the year may not significantly affect the EVI annual mean but may have broad ecological consequences in critical periods such as the start of the growing season.

\subsection{Application to forest monitoring and management}

Since satellite images are regularly captured over large regions and under common protocols, the spectral vegetation indices represent an adequate approach to implement ecosystems monitoring programs in protected areas and to promote adaptive management actions (Alcaraz-Segura et al., 2008a; Alcaraz-Segura et al., 2008b; Cabello et al., 2008). Our work provides interesting information for the prioritization and the orientation of management actions for the Pyrenean oak forests of Sierra Nevada National Park. First, we provided a regional functional reference characterization of all oak woodlands of the Park for the 2001-2009 period. Our monitoring approach uses EVI-derived descriptors of ecosystem functioning that may allow managers to detect the spatial and temporal anomalies (Oyonarte et al., 2010), and to guide specific management actions in particular areas. The spatial and temporal deviations from the baseline conditions detected could be alerting of inconspicuous "within-state" changes in the forests as a result of cumulative impacts (Vogelmann et al., 2009). However, to improve the ecological significance of this 
approach for the Park management, the monitoring program should include the identification of the key ecological processes that can be related to this functional description and that are central for the maintenance of the ecological integrity. For instance, the differences in the strength of the EVI trends among different oak forest patches could be associated to the two modes of climatic variability that affect Sierra Nevada. The observed weaker start of the growing season during study period could be related to the increase of positive phases of the North Atlantic Oscillation (NAO Index), which are the main control of winter precipitation and temperature, particularly in the north-western slope (Liras, 2011). In addition, we also observed EVI increases during the summer (July-August) in the southern slope (Figure 4), which could be related to the increase of active phases of the Western Mediterranean Oscillation (WeMO), increasing late summer precipitation during the study period (Liras, 2011; Cabello et al., Accepted). In this sense, the obtained results in the EVI trends for the different woods could be used to prioritize management actions in relation to climate change adaptation in the most threatened sites. Nevertheless, this should be only one of the guiding hypotheses for adaptive management, since other processes such as insect damage and forest succession could also be taking place in the park (Sierra Nevada National Park managers, personal communication, Stöver et al., 1996; CMJA, 2008).

A monitoring system based on the tools and analysis shown here could embrace several monitoring objectives, as it simultaneously informs managers about the changes in productivity, phenology, and seasonality of the ecosystems. For example, changes in the EVI attributes could be directly related to changes in the amount, seasonality, and phenology of ecosystem carbon gains. In addition, linking the EVI dynamics of the Pyrenean oak woodlands to the ecology of species of conservation concern could be used to evaluate and monitor the conservation status of the habitat of such species. This could be the case of the blue tit (Parus caeruleus), whose reproductive success is related to the ecosystem status of Quercus pyrenaica forests, especially at the beginning of female reproductive period (AprilMay), which is associated with the start of the growing season (Arriero et al., 2006). Such association implies that delays in the start of the growing season or forest degradation would negatively affect the reproduction success of this bird. Moreover, the information derived from this monitoring approach could help guiding land-use planning to avoid overexploitation of Sierra Nevada oak woodlands. For instance, livestock pressure should be limited in those periods of the year that are experiencing strong negative EVI trends.

\section{Conclusions}

Our approach shows how satellite based monitoring systems can be very useful to assess the effects of environmental changes on protected areas and to orientate adaptive management actions. Overall, this study provides a reference characterization against which to assess changes in ecosystem functioning of the oak woods of Sierra Nevada, and identifies functional changes that occurred during the 2001-2009 period. Such information helps to fill the lack of knowledge about these woodlands, as demanded by the Spanish Ministry of Environment (García \& Mejías, 2009). In practical terms, it allows the incorporation of ecosystem functional aspects of ecosystems to nature conservation and to the maintenance of ecosystem services, in particular those related to carbon sequestration in this protected area. Our results imply that conservation and management policies cannot be only based on static situations, since ecosystems are changing. In addition, annual summaries are not enough as monitoring indicators, since functional changes may occur at key seasonal stages without affecting the annual means. 

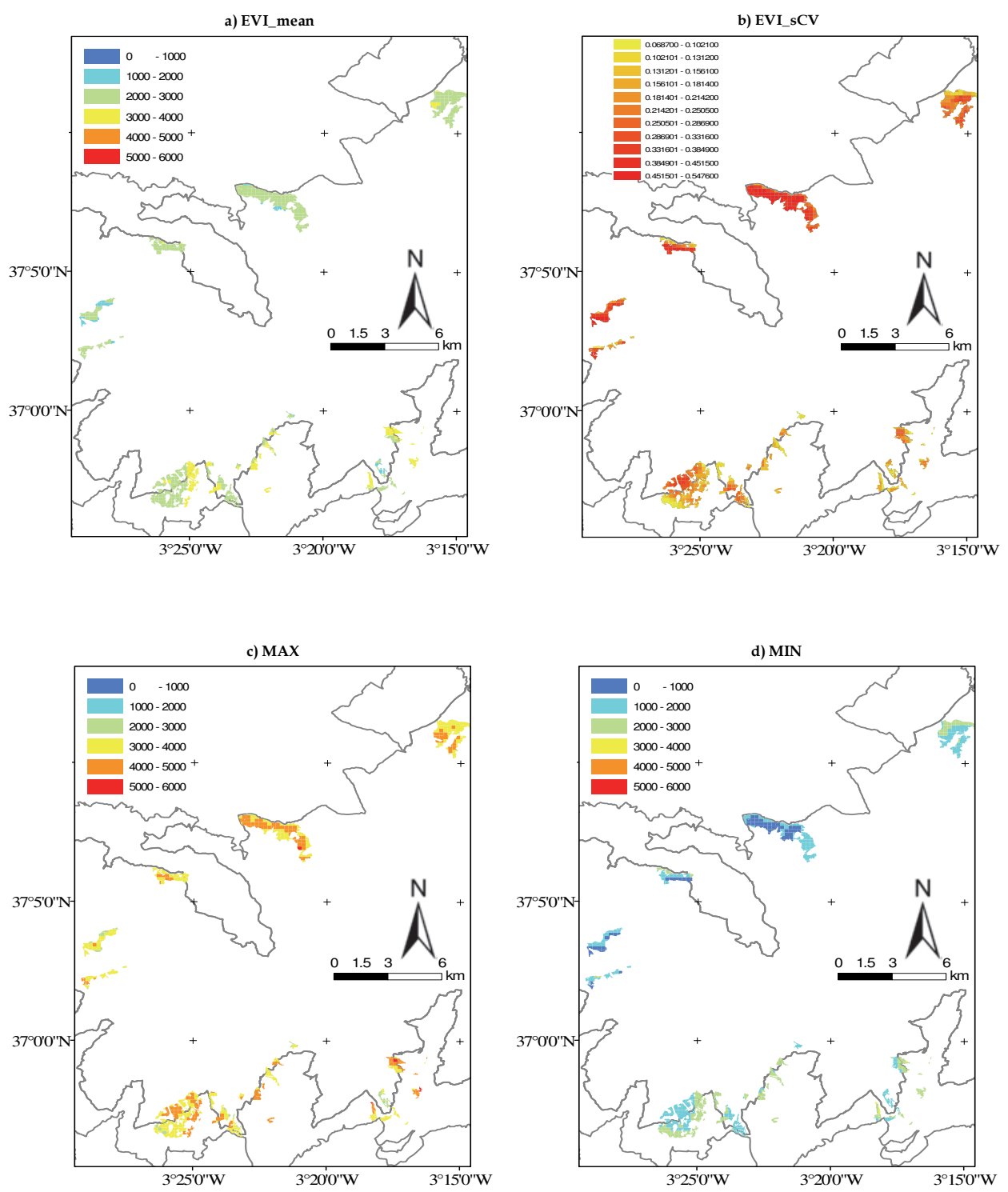

Fig. 6. Maps of the EVI attributes for Sierra Nevada Oak woods generated by the Monparq application. EVI_mean: EVI annual mean, an estimator of annual primary production; EVI_sCV: EVI seasonal Coefficient of Variation, a descriptor of seasonality; MAX and MIN: Maximum and Minimum EVI annual values, indicators of the maximum and minimum photosynthetic activity. 

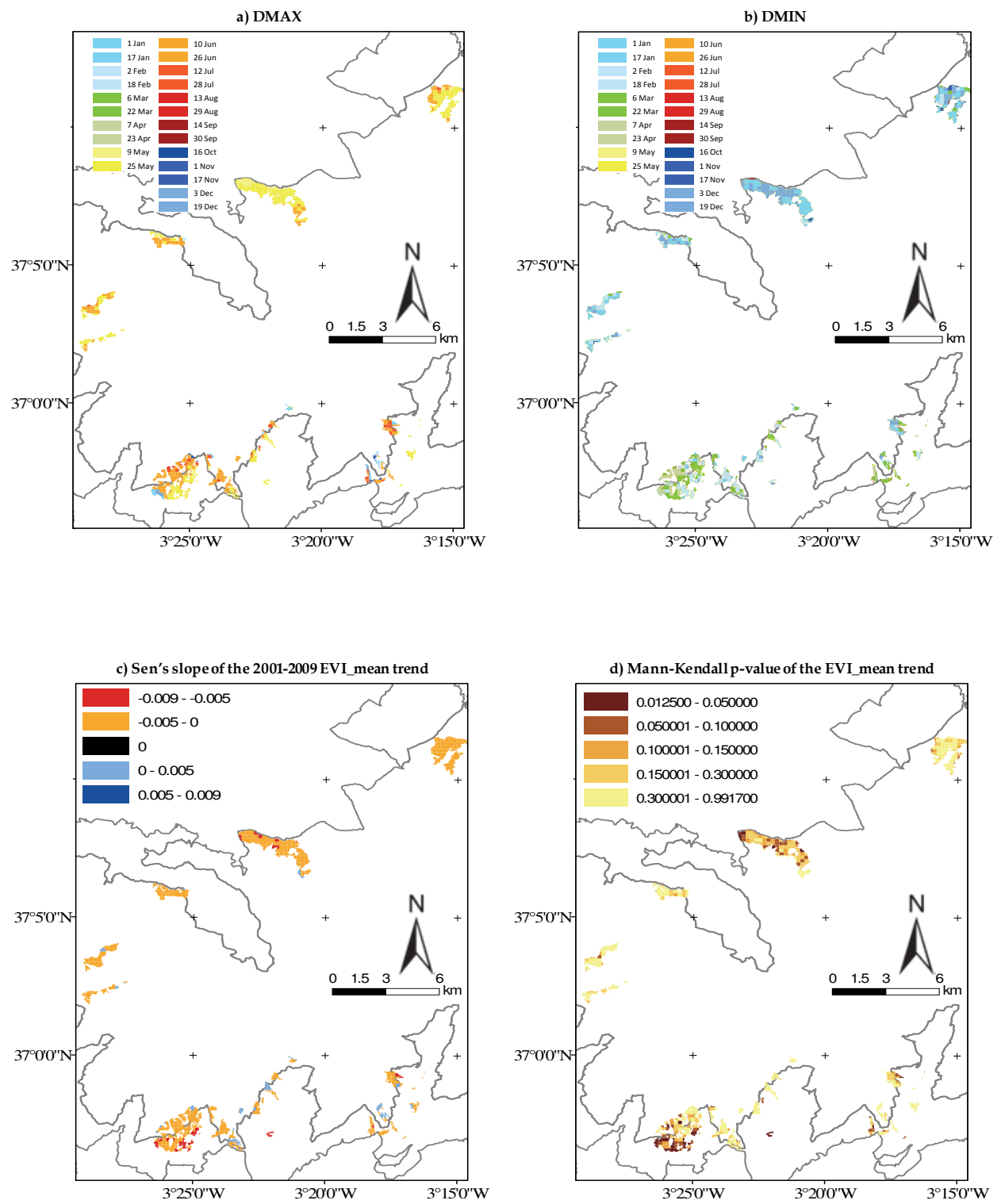

Fig. 7. Maps of the EVI attributes and trends for Sierra Nevada Oak woods generated by the Monparq application. a) DMAX and b) DMIN: Dates when the Maximum and Minimum EVI values are reached, indicators of phenology. c) Sen's slope of the 2001-2009 EVI_mean trend d) Mann-Kendall p-value of the 2001-2009 EVI_mean trend. 


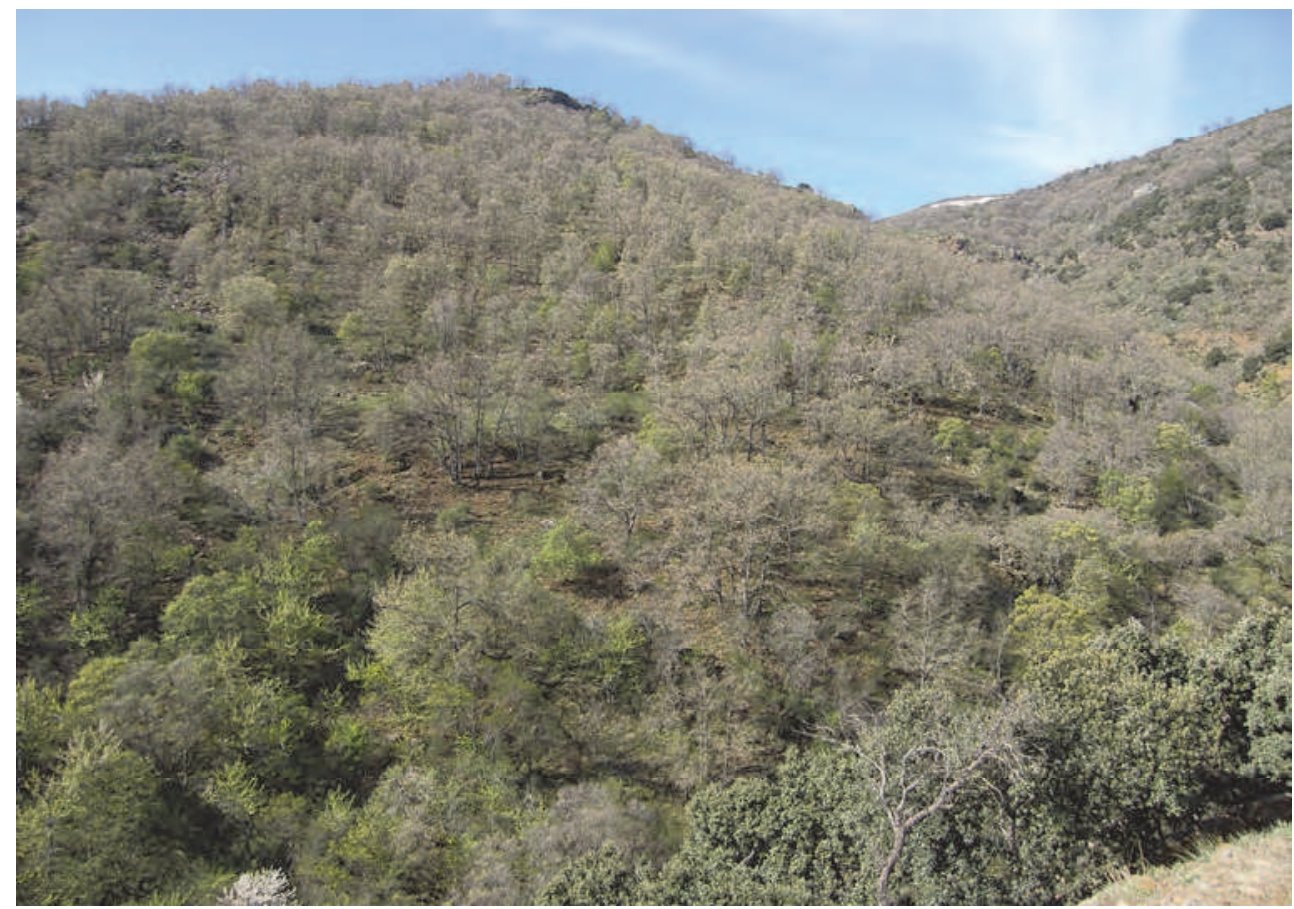

Fig. 8. Landscape picture showing the start of the growing season (13 th April 2011) in the northernmost Quercus pyrenaica oak wood of Sierra Nevada National Park (Spain), the oak wood of the Alhama River at Dehesa del Camarate. The picture shows how the green sprouts of the oak trees are starting to come out while the leaves of the undergrowth shrubs are well developed.

To spread the use of our monitoring approach and to make possible for managers the exploitation of such information, we have developed a software tool named "Monparq Monitoring System for Parks" that allows a non-advance user to assess the differences between locations, to explore the different environmental controls across the northern and southern slopes, and to evaluate the inter-annual trends in ecosystem functioning. This tool provides managers with valuable information to assess management effectiveness in an adaptive management strategy. It will help managers answering questions like, what ecosystems are undergoing major changes?, or how do management actions affect ecosystem functioning stability?

\section{Acknowledgments}

Thanks to L. Sevilla, who helped processing the datasets, to F.J. Bonet and B. Benito from the Sierra Nevada Global Change Observatory for providing climate data, to the Park managers and J. del Río from the Andalusian Environmental Agency for their guidance and valuable information in the field, and to F. Maestre for the English revision. Financial support was given by FEDER Funds, Junta de Andalucía (GLOCHARID and SEGALERT P09-RNM-5048 projects), Organismo Autónomo de Parques Nacionales (Proyecto 066/2007), and Ministerio 
de Ciencia e Innovación (Proyecto CGL2010-22314, subprograma BOS, Plan Nacional I+D+I 2010). D. Alcaraz-Segura was partially covered by the Inter-American Institute for Global Change Research (IAI, CRN II 2031 and 2094) under the US National Science Foundation (Grant GEO-0452325). The trend test was run using the MATLAB code "Seasonal Kendall Test with Slope for Serial Dependent Data" provided by Jeff Burkey through the MATLAB Central file exchange (http://www.mathworks.com, accessed September 2009). Satellite images were freely provided by the MODIS Land website.

\section{References}

Alcaraz-Segura, D.; Baldi, G.; Durante, P. \& Garbulsky, M. (2008a). Análisis de la dinámica temporal del NDVI en áreas protegidas: tres casos de estudio a distintas escalas espaciales, temporales y de gestión. Ecosistemas, Vol.17, No.3, pp. 108-117, ISSN 1697-2473

Alcaraz-Segura, D.; Cabello, J.; Paruelo, J.M. \& Delibes, M. (2008b). Trends in the surface vegetation dynamics of the National Parks of Spain as observed by satellite sensors. Applied Vegetation Science, Vol.11, pp. 431-440, ISSN 1402-2001

Alcaraz-Segura, D.; Cabello, J. \& Paruelo, J. (2009a). Baseline characterization of major Iberian vegetation types based on the NDVI dynamics. Plant Ecology, Vol.202, No.1, pp. 13-29, ISSN 1385-0237

Alcaraz-Segura, D.; Cabello, J.; Paruelo, J.M. \& Delibes, M. (2009b). Use of descriptors of ecosystem functioning for monitoring a national park network: A remote sensing approach. Environmental Management, Vol.43, No.1, January, pp. 38-48, ISSN 14321009 (Electronic), 0364-152X (Linking)

Alcaraz-Segura, D.; Chuvieco, E.; Epstein, H.E.; Kasischke, E.S. \& Trishchenko, A. (2010a). Debating the greening vs. browning of the North American boreal forest: differences between satellite datasets. Global Change Biology, Vol.16, No.2, pp. 760770, ISSN 1365-2486

Alcaraz-Segura, D.; Liras, E.; Tabik, S.; Paruelo, J. \& Cabello, J. (2010b). Evaluating the Consistency of the 1982-1999 NDVI Trends in the Iberian Peninsula across Four Time-series Derived from the AVHRR Sensor: LTDR, GIMMS, FASIR, and PAL-II. Sensors, Vol.10, No.2, pp. 1291-1314, ISSN 1424-8220

Alcaraz-Segura, D.; Paruelo, J. \& Cabello, J. (2006). Identification of current ecosystem functional types in the Iberian Peninsula. Global Ecology and Biogeography, Vol.15, No.2, pp. 200-212, ISSN 1466-8238

Arriero, E.; Sanz, J.J. \& Romero-Pujante, M. (2006). Habitat structure in Mediterranean deciduous oak forests in relation to reproductive success in the Blue Tit Parus caeruleus: Capsule Effects operate during laying and incubation and with less success in breeding territories characterized by a young and immature vegetation structure. Bird Study, Vol.53, No.1, pp. 12-19, ISSN 0006-3657

Baldi, G.; Nosetto, M.D.; Aragón, M.R.; Aversa, F.; Paruelo, J.M. \& Jobbagy, E.G. (2008). Long-term satellite NDVI datasets: Evaluating their ability to detect ecosystem functional changes in South America. Sensors, Vol.8, pp. 5397-5425, ISSN 14248220

Blanca, G. (2001). Flora, In: Parque Nacional de Sierra Nevada, Calvo-Flores D, (Ed.), 106-148, Esfagnos, ISBN 978-84-932095-1-3, 
Blanca, G.; Cueto, M.; Martínez-Lirola, M.J. \& Molero-Mesa, J. (1998). Threatened vascular flora of Sierra Nevada (Southern Spain). Biological Conservation, Vol.85, No.3, pp. 269-285, ISSN 0006-3207

Blanca, G. \& Mendoza, R.T. (2000). Libro rojo de la flora silvestre amenazada de Andalucía: Especies vulnerables, Junta de Andalucía, Consejería de Medio Ambiente, ISBN 97884-89650-75-6, Sevilla, España

Bonet, F.J.; Pérez-Luque, A.J.; Moreno, R. \& Zamora, R. (Septiembre 2010). Observatorio de Cambio Global de Sierra Nevada. Estructura y Contenidos Básicos. Consejería de Medio Ambiente, Junta de Andalucía, Available from

http:/ / www.scribd.com/doc/32239398/Observatorio-Sierra-Nevada-Datosbasicos

Cabello, J.; Alcaraz-Segura, D.; Altesor, A.; Delibes, M.; Baeza, S. \& Liras, E. (2008). Funcionamiento ecosistémico y evaluación de prioridades geográficas en conservación. Ecosistemas, Vol.17, No.3, pp. 53-63, ISSN 1697-2473

Cabello, J.; Alcaraz-Segura, D.; Ferrero, R.; Castro, A.J. \& Liras, E. (Accepted). The role of vegetation and lithology in the spatial and inter-annual response of EVI to climate in drylands of Southeastern Spain. Journal of Arid Environments, ISSN 0140-1963

Cabello, J.; Alcaraz-Segura, D.; Liras, E. \& Sevilla-García, L. (2010). Monparq, una plataforma informática para el seguimiento de los Parques Nacionales. Centro Andaluz para la Evaluación y Seguimiento del Cambio Global (CAESCG)

CMJA. (Noviembre 2008). Consejería de Medio Ambiente. Borrador de la adecución del Plan Forestal Andaluz para el periodo 2008-2015. Dirección General de Planificación e Información Ambiental, Available from

http:/ / www.juntadeandalucia.es/medioambiente/site/web/menuitem.a5664a2 14f73c3df81d8899661525ea0/?vgnextoid=e45601c4bd997110VgnVCM1000000624 e50aRCRD\&vgnextchannel=3259b19c7acf2010VgnVCM1000001625e50aRCRD\&lr =lang_es

Costa Tenorio, M.; Morla Juaristi, C. \& Sainz Ollero, H. (2005). Los bosques ibéricos. Una interpretación geobotánica, Planeta, ISBN 978-84-08058-20-5, Barcelona

Chu, D.; Kaufman, Y.; Zibordi, G.; Chern, J.; Mao, J.; Li, C. \& Holben, B. (2003). Global monitoring of air pollution over land from the Earth observing System-Terra Moderate Resolution Imaging Spectroradiometer (MODIS). Journal of Geophysical Research, Vol.108, No.D21, ISSN 0148-0227

Dale, V.H. \& Beyeler, S.C. (2001). Challenges in the development and use of ecological indicators. Ecological indicators, Vol.1, No.1, pp. 3-10, ISSN 1470-160X

García, I. \& Mejías, P.J. (2009). 9230 Robledales de Quercus pyrenaica y robledales de Quercus robur y Quercus pyrenaica del noroeste ibérico. Bases ecológicas preliminares para la conservación de los tipos de hábitat de interés comunitario en España, Ministerio de Medio Ambiente y Medio Rural y Marino, ISBN 978-84-491-0911-9, Madrid, España

Hanan, N.; Prince, S. \& Begue, A. (1995). Estimation of absorbed photosynthetically active radiation and vegetation net production efficiency using satellite data. Agricultural and forest meteorology, Vol.76, No.3-4, pp. 259-276, ISSN 0168-1923

Hirsch, R.M.; Slack, J.R. \& Smith, R.A. (1982). Techniques of trend analysis for monthly water quality data. Water resources research, Vol.18, No.1, pp. 107-121, ISSN 00431397 
Huete, A.R.; Liu, H.Q.; Batchily, K. \& van Leeuwen, W. (1997). A comparison of vegetation indices over a global set of TM images for EOS-MODIS. Remote Sensing of Environment, Vol.59, No.3, pp. 440-451, ISSN 0034-4257

Kharuk, V.; Ranson, K.; Kuz'michev, V. \& Im, S. (2003). Landsat-based analysis of insect outbreaks in southern Siberia. Canadian journal of remote sensing, Vol.29, No.2, pp. 286, ISSN 0703-8992

Liras, E. (2011). Funcionamiento ecosistémico: Controles y patrones espacio-temporales en el SE Ibérico, Universidad de Almería, ISBN 978-84-8240-967-2, Almería, España

Lovett, G.M.; Burns, D.A.; Driscoll, C.T.; Jenkins, J.C.; Mitchell, M.J.; Rustad, L.; Shanley, J.B.; Likens, G.E. \& Haeuber, R. (2007). Who needs environmental monitoring? Frontiers in Ecology and the Environment, Vol.5, No.5, pp. 253-260, ISSN 1540-9295

Lovett, G.M.; Canham, C.D.; Arthur, M.A.; Weathers, K.C. \& Fitzhugh, R.D. (2006). Forest ecosystem responses to exotic pests and pathogens in eastern North America. BioScience, Vol.56, No.5, pp. 395-405, ISSN 0006-3568

Martínez, B. \& Gilabert, M.A. (2009). Vegetation dynamics from NDVI time series analysis using the wavelet transform. Remote Sensing of Environment, Vol.113, No.9, pp. 18231842, ISSN 0034-4257

McNaughton, S.J.; Oesterheld, M.; Frank, D.A. \& Williams, K.J. (1989). Ecosystem-level patterns of primary productivity and herbivory in terrestrial habitats. Nature, Vol.341, No.6238, 14 September, pp. 142-144, ISSN 0028-0836

Milchunas, D. \& Lauenroth, W. (1995). Inertia in plant community structure: state changes after cessation of nutrient-enrichment stress. Ecological Applications, Vol.5, No.2, pp. 452-458, ISSN 1051-0761

MMARM. (2004). Ministerio de Medio Ambiente y Medio Rural y Marino. Parque Nacional de Sierra Nevada, Available from

http://reddeparquesnacionales.mma.es/parques/org_auto/red_ppnn/parques/1 0_sierra.htm

Molero, J.; Pérez-Raya, F.; Tendero, F.V. \& González-Tejero, M.R. (1992). Parque Natural de Sierra Nevada: paisaje, fauna, flora e itinerarios, Rueda, ISBN 978-84-72070-67-0, Madrid, España

Monteith, J. (1972). Solar radiation and productivity in tropical ecosystems. Journal of Applied Ecology, Vol.9, No.3, pp. 747-766, ISSN 0021-8901

Mueller-Dombois, D. \& Ellenberg, H. (1974). Aims and methods of vegetation ecology, John Wiley \& Sons, ISBN 978-1-930665-73-6, New York, EE.UU

Oyonarte, C.; Alcaraz-Segura, D.; Oyarzabal, M.; Paruelo, J.M. \& Cabello, J. (2010). Sistema de apoyo a la gestión de reservas de la biosfera basado en el monitoreo de la productividad primaria: ensayo en Cabo de Gata-Níjar (Almería-España), In: Reservas de la Biosfera: Su contribución a la provisión de servicios de los ecosistemas, experiencias exitosas en Iberoamérica, Araya P, Clüsener-Godt M, (Ed.), 119-140, UNESCO, ISBN 978-956-332-417-4, Paris

Paruelo, J.; Alcaraz-Segura, D. \& Volante, J.N. (2011). El seguimiento del nivel de provisión de los servicios ecosistémicos, In: Valoración de Servicios Ecosistémicos: Conceptos, Herramientas y Aplicaciones para el Ordenamiento Territorial, Laterra P, E. Jobbágy \& J. Paruelo, (Ed.), 141-162, Ediciones INTA, ISBN 978-987-679-018-5, Buenos Aires 
Paruelo, J.M.; Epstein, H.E.; Lauenroth, W.K. \& Burke, I.C. (1997). ANPP estimates from NDVI for the central grassland region of the United States. Ecology, Vol.78, No.3, pp. 953-958, ISSN 0012-9658

Paruelo, J.M.; Piñeiro, G.; Oyonarte, C.; Alcaraz-Segura, D.; Cabello, J. \& Escribano, P. (2005). Temporal and spatial patterns of ecosystem functioning in protected and areas in southeastern Spain. Applied Vegetation Science, Vol.8, No.1, pp. 93-102, ISSN 14022001

Perry, G.L.W. \& Millington, J.D.A. (2008). Spatial modelling of succession-disturbance dynamics in forest ecosystems: Concepts and examples. Perspectives in Plant Ecology, Evolution and Systematics, Vol.9, No.3-4, pp. 191-210, ISSN 1433-8319

Pettorelli, N.; Vik, J.O.; Mysterud, A.; Gaillard, J.M.; Tucker, C.J. \& Stenseth, N.C. (2005). Using the satellite-derived NDVI to assess ecological responses to environmental change. Trends in Ecology \& Evolution, Vol.20, No.9, pp. 503-510, ISSN 0169-5347

Riano, D.; Chuvieco, E.; Ustin, S.; Zomer, R. \& Dennison, P. (2002). Assessment of vegetation regeneration after fire through multitemporal analysis of AVIRIS images in the Santa Monica Mountains. Remote Sensing of Environment, Vol.79, No.1, pp. 60-71, ISSN 0034-4257

Sanyal, J. \& Lu, X. (2004). Application of remote sensing in flood management with special reference to monsoon Asia: a review. Natural Hazards, Vol.33, No.2, pp. 283-301, ISSN 0921-030X

Stephenson, N.L. (1990). Climatic control of vegetation distribution: the role of the water balance. The American Naturalist, Vol.135, No.5, pp. 649-670, ISSN 0003-0147

Stöver, O.; Horst, D.; Engels, F.; Joachim, H. \& Atzberger, C. (1996). An assessment of forest areas damaged by a Gypsy Moth infestation through satellite remote sensing and GIS, In: Application of remote sensing in European forest monitoring, Kennedy P, (Ed.), 359-372, Commission of the European Communities, Viena, Austria

Tucker, C.J. \& Choudhury, B.J. (1987). Satellite remote sensing of drought conditions. Remote Sensing of Environment, Vol.23, No.2, pp. 243-251, ISSN 0034-4257

Turner, M.G. (2005). Landscape ecology: What is the state of the science? Annual Review of Ecology, Evolution, and Systematics, Vol.36, pp. 319-344, ISSN 1543-592X

Virginia, R. \& Wall, D. (2001). Principles of ecosystem function, In: Encyclopedia of biodiversity, Levin SA, (Ed.), 345-352, Academic Press, ISBN 0122268652, San Diego, USA

Vogelmann, J.E.; Tolk, B. \& Zhu, Z. (2009). Monitoring forest changes in the southwestern United States using multitemporal Landsat data. Remote Sensing of Environment, Vol.113, No.8, pp. 1739-1748, ISSN 0034-4257

Volante, J.N.; Alcaraz-Segura, D.; Mosciaro, M.J.; Viglizzo, E.F. \& Paruelo, J.M. (In press). Ecosystem functional changes associated with land clearing in NW Argentina. Agriculture, Ecosystems and Environment, ISSN 0167-8809

Wiegand, T.; Snyman, H.A.; Kellner, K. \& Paruelo, J.M. (2004). Do grasslands have a memory: modeling phytomass production of a semiarid South African grassland. Ecosystems, Vol.7, No.3, pp. 243-258, ISSN 1432-9840

Yuan, M.; Dickens-Micozzi, M. \& Magsig, M.A. (2002). Analysis of tornado damage tracks from the 3 May tornado outbreak using multispectral satellite imagery. Weather and forecasting, Vol.17, No.3, pp. 382-398, ISSN 1520-0434 


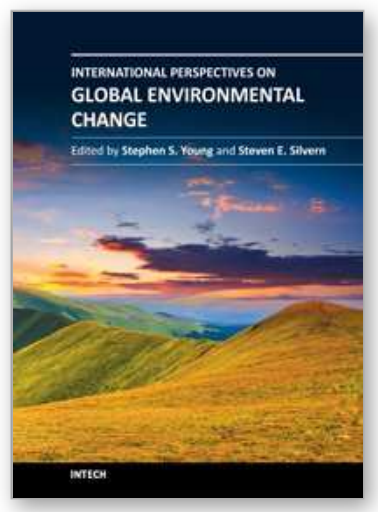

\author{
International Perspectives on Global Environmental Change \\ Edited by Dr. Stephen Young
}

ISBN 978-953-307-815-1

Hard cover, 488 pages

Publisher InTech

Published online 03, February, 2012

Published in print edition February, 2012

Environmental change is increasingly considered a critical topic for researchers across multiple disciplines, as well as policy makers throughout the world. Mounting evidence shows that environments in every part of the globe are undergoing tremendous human-induced change. Population growth, urbanization and the expansion of the global economy are putting increasing pressure on ecosystems around the planet. To understand the causes and consequences of environmental change, the contributors to this book employ spatial and nonspatial data, diverse theoretical perspectives and cutting edge research tools such as GIS, remote sensing and other relevant technologies. International Perspectives on Global Environmental Change brings together research from around the world to explore the complexities of contemporary, and historical environmental change. As an InTech open source publication current and cutting edge research methodologies and research results are quickly published for the academic policy-making communities. Dimensions of environmental change explored in this volume include: Climate change Historical environmental change Biological responses to environmental change Land use and land cover change Policy and management for environmental change

\title{
How to reference
}

In order to correctly reference this scholarly work, feel free to copy and paste the following:

M.A. Dionisio, D. Alcaraz-Segura and J. Cabello (2012). Satellite-Based Monitoring of Ecosystem Functioning in Protected Areas: Recent Trends in the Oak Forests (Quercus pyrenaica Willd.) of Sierra Nevada (Spain), International Perspectives on Global Environmental Change, Dr. Stephen Young (Ed.), ISBN: 978-953-307815-1, InTech, Available from: http://www.intechopen.com/books/international-perspectives-on-globalenvironmental-change/satellite-based-monitoring-of-ecosystem-functioning-in-protected-areas-recent-trendsin-the-oak-fore

\section{INTECH}

open science | open minds

\author{
InTech Europe \\ University Campus STeP Ri \\ Slavka Krautzeka 83/A \\ 51000 Rijeka, Croatia \\ Phone: +385 (51) 770447 \\ Fax: +385 (51) 686166 \\ www.intechopen.com
}

\author{
InTech China \\ Unit 405, Office Block, Hotel Equatorial Shanghai \\ No.65, Yan An Road (West), Shanghai, 200040, China \\ 中国上海市延安西路65号上海国际贵都大饭店办公楼 405 单元 \\ Phone: +86-21-62489820 \\ Fax: +86-21-62489821
}


(C) 2012 The Author(s). Licensee IntechOpen. This is an open access article distributed under the terms of the Creative Commons Attribution 3.0 License, which permits unrestricted use, distribution, and reproduction in any medium, provided the original work is properly cited. 